\title{
Outbreak
}

\section{An outbreak of influenza A(H3N2) in Alappuzha district, Kerala, India, in 2011}

\author{
Sam Peter ${ }^{1}$, Anukumar Balakrishnan ${ }^{1}$, Varsha A Potdar², Mandeep S Chadha², Santosh M Jadhav² \\ ${ }^{1}$ National Institute of Virology (NIV), Kerala Unit, Medical College Hospital Complex, Alappuzha, Kerala, India \\ ${ }^{2}$ National Institute of Virology (NIV), Pune, India
}

\begin{abstract}
Introduction: Influenza is an RNA virus that belongs to the Orthomyxoviridae family. It causes a highly contagious acute respiratory illness, has been recognized since ancient times, and is a major health threat throughout the world. An outbreak of influenza-like illness (ILI) was reported from Alappuzha district of Kerala State between late June and July 2011. This investigation was conducted to determine the clinical picture, causative agents, and epidemiological characteristics of the illness.

Methodology: The World Health Organization (WHO)'s case definition for ILI was followed throughout the investigation. Nasal or throat swabs were collected from 204 suspected patients. Real-time reverse transcription polymerase chain reaction (RT-PCR)-based diagnosis was performed to detect influenza A and B viruses and their subtypes. Madin-Darby canine kidney (MDCK) cell line was used for virus isolation. One-step RT-PCR was performed to amplify the HA1 gene of influenza A(H3N2). The amplicons for the HA1 gene of influenza A(H3N2) were sequenced, and phylogenetic analysis was done.

Results: Analysis of the data revealed that $96(47.05 \%)$ of the 204 respiratory specimens collected were influenza A(H3N2) and only 6 $(2.94 \%)$ were $\mathrm{A}(\mathrm{H} 1 \mathrm{~N} 1) \mathrm{pdm} 09$. Phylogenetic analysis revealed that the isolated A(H3N2) was closely related to the $2012-2013$ northern hemisphere vaccine strain (A/Victoria/361/2011/H3N2).

Conclusions: An influenza A(H3N2) outbreak was confirmed in Alappuzha district of Kerala state with a co-circulation of A(H1N1)pdm09. No substantial difference in the sequence was observed in the etiological agent, and the virus was found to be sensitive to oseltamivir.
\end{abstract}

Key words: India; influenza A(H3N2); influenza-like illness; influenza virus; Kerala; outbreak.

J Infect Dev Ctries 2015; 9(4):362-367. doi:10.3855/jidc.5723

(Received 08 August 2014 - Accepted 05 February 2015)

Copyright ( 2015 Peter et al. This is an open-access article distributed under the Creative Commons Attribution License, which permits unrestricted use, distribution, and reproduction in any medium, provided the original work is properly cited.

\section{Introduction}

Influenza is an RNA virus that belongs to the Orthomyxoviridae family. It causes a highly contagious acute respiratory illness, has been recognized since ancient times, and is a major health threat throughout the world [1]. The influenza A virus undergoes minor antigenic changes from year to year and may also undergo a major change, termed an antigenic shift, which can cause a pandemic [2,3]. Recently, many countries experienced resurgent outbreaks due to H1N1 influenza A pandemic of 2009 (A(H1N1)pdm09) [4].In India, the first confirmed case of A(H1N1)pdm09 was reported on 16 May 2009 [5]. The influenza $\mathrm{A}(\mathrm{H} 3 \mathrm{~N} 2)$ virus responsible for the 1968 influenza pandemic is also a major cause of morbidity and mortality worldwide [6]. Co-circulation of both $\mathrm{A}(\mathrm{H} 1 \mathrm{~N} 1) \mathrm{pdm} 09$ and influenza $\mathrm{A}(\mathrm{H} 3 \mathrm{~N} 2)$ viruses have been detected in various parts of Asia, Europe, and North America [7]. In India, the activity of influenza A(H3N2) was reported from the states of Maharashtra, Andhra Pradesh, Kolkata, and other regions [8]. Even though several studies have documented the endemic transmission of influenza $\mathrm{A}(\mathrm{H} 3 \mathrm{~N} 2)$ in India, no data have been published from the southern states of India such as Kerala.

In view of the public health importance, the Indian Council of Medical Research (ICMR) in collaboration with the Centers for Disease Control and Prevention (CDC) established a network of systematic laboratories to monitor the activities of influenza viruses. The Kerala Unit of the National Institute of Virology (NIV), a branch of the National Institute of Virology, Pune, was included in this network in 2010. This networked surveillance system collects epidemiological data and clinical specimens from patients presenting for influenza-like illnesses (ILIs). Through this surveillance network, clusters of respiratory illness in various settings are detected, and a global snapshot of influenza trends, particularly regarding circulating and emerging strains, is developed. 
Through this surveillance, we detected an ILI outbreak in Alappuzha, Kerala. We report here the findings of the investigations conducted to confirm the etiology of the illness.

\section{Methodology}

Study area and setting

Kerala lies at the southern end of the Indian peninsula and has a population of 33.38 million (2011 census). The population studied lived in Alappuzha district of the state of Kerala. Alappuzha is a district with the Arabian Sea on the west, and a vast network of backwaters, lagoons, and freshwater rivers crisscrossing the land (Figure 1). The district lies between $9^{\circ} 5^{\prime}$ north latitude and $76^{\circ} 17^{\prime}$ and $76^{\circ} 44^{\prime}$ east longitudes. The total geographical area is $1,414 \mathrm{~km}^{2}$, and the district has a coastline of $82 \mathrm{~km}$. This district has a population of $2,127,789$, with $1,013,142$ men and 1,114,647 women. The economy of the district is based predominantly on agriculture and marine products. Owing to its proximity to the sea, the climate of Alappuzha is humid and hot during the summer. The region experiences a long monsoon season with heavy showers, as both the southwest and northeast monsoons influence the weather of Alappuzha. The southwest monsoon affects the climate in between the end of May to September. On the other hand, the northeast monsoon brings rain from October to

Figure 1. India map showing location of Kerala State (black color). The Alappuzha district is indicated in Kerala State map (grey color).

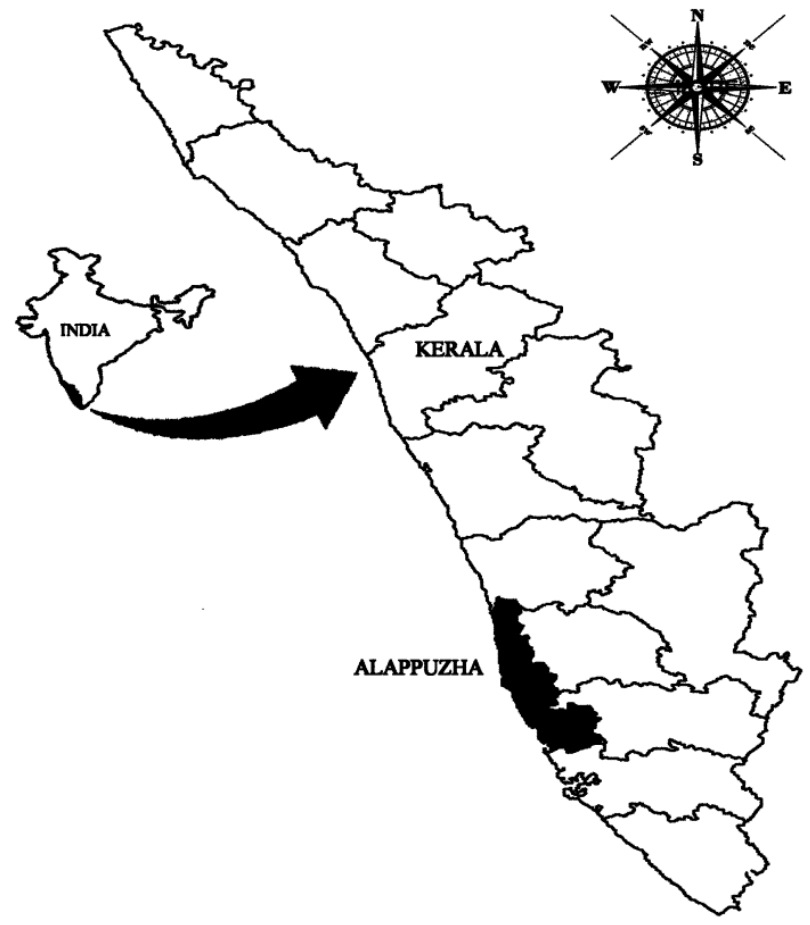

November. Alappuzha has a government Medical College Hospital and many primary health centers. The NIV Kerala Unit, an influenza surveillance network regional centre, is situated in the Medical College Hospital Complex of Vandanam, Alappuzha. The unit has six sentinel sites in different parts of the district; samples were collected from the outpatient wards of all sentinel hospitals.

\section{Case definition of ILI}

Cases were defined as ILI in patients presenting with sudden onset of fever $>38^{\circ} \mathrm{C}$ or history of sudden onset of fever in the recent past (less than three days), cough, or sore throat and/or rhinorrhea in the absence of other diagnosis [9].

\section{Meteorological data}

Meteorological data were collected from the government meteorological department of Kerala. Monthly data were collected for average rainfall for the entire year, including monsoon and other seasons.

\section{Ethical clearance}

Protocols and measures used in the study were reviewed and approved by the institutional ethical committee of the National Institute of Virology, India, in accordance with the ethical standards of the Declaration of Helsinki. The outbreak was investigated as a part of the surveillance program. Written consent from participants was obtained before collection of the respiratory specimens.

\section{Description of the outbreak}

There was a sharp increase in the number of ILI patients in one of the sentinel hospitals in the district. All patients were extremely exhausted, and the majority suffered from cough at the time of presentation to the hospital. Participating physicians were asked to complete a brief questionnaire for each patient. After a quick but careful investigation, respiratory specimens were collected from each patient. In the subsequent day onwards, several patients with ILI visited the sentinel hospitals. As a result of this increased rate of respiratory illness and a desire to identify the etiology and scope of the illness, augmented surveillance for ILI cases was performed during the outbreak period.

\section{Specimen collection and processing}

The respiratory specimens (nasal or throat swabs) were collected from patients who fit into the World Health Organization (WHO)'s ILI case definition. A 
total of 204 nasal or throat swab specimens were collected during the period of outbreak from patients of all age groups with acute respiratory illness. Collected swab specimens were then placed in sterile screw-capped containers with viral transport media (VTM) and transported, in ice, to the laboratory. Swab specimens were gently agitated and extracted for further processing. The extracts were kept at $-80^{\circ} \mathrm{C}$ until used [10].

RNA extraction and real-time reverse transcription polymerase chain reaction (real-time $R T-P C R$ )

RNA was extracted from clinical specimens using the QIAmpViral RNA Mini Kit protocol (Qiagen, Hilden, Germany). The extracted RNA was tested by real-time RT-PCR using SuperScript III One-Step RTPCR System (Invitrogen,Carlsbad, USA)with PlatinumTaq reagents and primers and probes from the CDC human influenza virus real-time RT-PCR detection and characterization panel [11]. The four targets tested were universal influenza A (InfA), universal swine A (SwFluA), pandemic influenza A (H1N1)2009 (A[H1N1]pdm09), and RNase P (RP). The RNase $\mathrm{P}$ primer and probe set targets the human RNase $\mathrm{P}$ gene and thus served as an internal positive control for human nucleic acid. All the specimens that give a presumptive negative for $\mathrm{A}(\mathrm{H} 1 \mathrm{~N} 1) \mathrm{pdm} 09$ but were universal influenza A positive were further examined for seasonal influenza $\mathrm{A}(\mathrm{H} 1 \mathrm{~N} 1)$ and $\mathrm{A}(\mathrm{H} 3 \mathrm{~N} 2)$, and those specimens negative for universal influenza A were tested for influenza B virus.

\section{Virus isolation in cell culture}

One hundred $\mu \mathrm{L}$ of supernatant of nasal or throat swab specimens (real-time RT-PCR-positive patients) were inoculated into Madin-Darby canine kidney (MDCK) cells prepared in 24-well multiple well tissue culture plates. The plates were kept at $37^{\circ} \mathrm{C}$ under $5 \%$ $\mathrm{CO}_{2}$ atmosphere up to seven days [10]. The inoculated MDCK cell line was observed for cytopathic effects, following which the tissue culture fluid was harvested.
All cultures were screened by real-time RT-PCR to detect viral presence. The obtained isolates were extracted for RNA, and aliquots were stored at $-80^{\circ} \mathrm{C}$ for further analysis.

\section{Sequence analysis}

Viral RNA was extracted from culture supernatant of the selected isolates using the QIAamp Viral RNA Mini Kit (Qiagen) as described earlier [12]. One step RT-PCR (Superscript III Platinum One-Step RT-PCR Kit, Invitrogen) was performed to amplify the HA1 gene of $\mathrm{A}(\mathrm{H} 3 \mathrm{~N} 2)$. Amplified fragment (980 bp) was visualized by ethidium bromide (EtBr) agarose gel staining.

\section{Sequencing}

The amplicons for the HA1 gene of influenza $\mathrm{A}(\mathrm{H} 3 \mathrm{~N} 2)$ were purified using a QIAquick PCR purification kit (Qiagen). DNA sequencing was carried out using Big Dye Terminator v3.1 Cycle Sequencing Ready Reaction Kit (ABI, Foster City, USA) as described earlier [13], and unincorporated labeled ddNTPs were removed using the DyeEX 2.0 Spin Kit (Qiagen). The sequencing was done on an ABI 3730 DNA Analyzer, and the sequences were analyzed in MEGA 4 program [14]. The sequences were submitted to GenBank.

\section{Phylogenetic analysis}

MEGA version 4 [14] was used for constructing HA1 gene-based neighbor-joining (NJ) trees using Kimura's two-parameter distance model, with 1,000 bootstrap replicates. The percent nucleotide identity (PNI) and percent amino acid identity (PAI) values were calculated as pairwise $\mathrm{p}$-distances.

\section{Results}

From June to July 2011, 204 patients that met the ILI case definition were identified through sentinel hospital-based surveillance $(\mathrm{n}=204)$. A preliminary test conducted on 30 June 2011 revealed the presence

Table 1. Age group wise distribution of study population $(n=204)$ showing total number of influenza like illness cases and influenza A(H3N2)-positive cases.

\begin{tabular}{ccc}
\hline Age group(years) & ILI* population & Number of influenza A(H3N2)-positive cases (\%) \\
\hline $0-5$ & 52 & $32(33.33)$ \\
$6-14$ & 24 & $10(10.42)$ \\
$15-30$ & 64 & $25(26.04)$ \\
$31-44$ & 40 & $21(21.8)$ \\
$45-59$ & 22 & $6(6.25)$ \\
60 and above & 2 & $2(2.08)$ \\
Total & $\mathbf{2 0 4}$ & $\mathbf{9 6}(\mathbf{1 0 0})$ \\
\hline
\end{tabular}


Figure 2. The graph shows that month-wise distribution of absolute number of influenza-like illness cases and real time RT-PCR positive influenza $\mathrm{A}(\mathrm{H} 3 \mathrm{~N} 2)$ and $\mathrm{A}(\mathrm{H} 1 \mathrm{~N} 1) \mathrm{pdm} 09$ cases, and average rainfall (mm) during the year 2011.

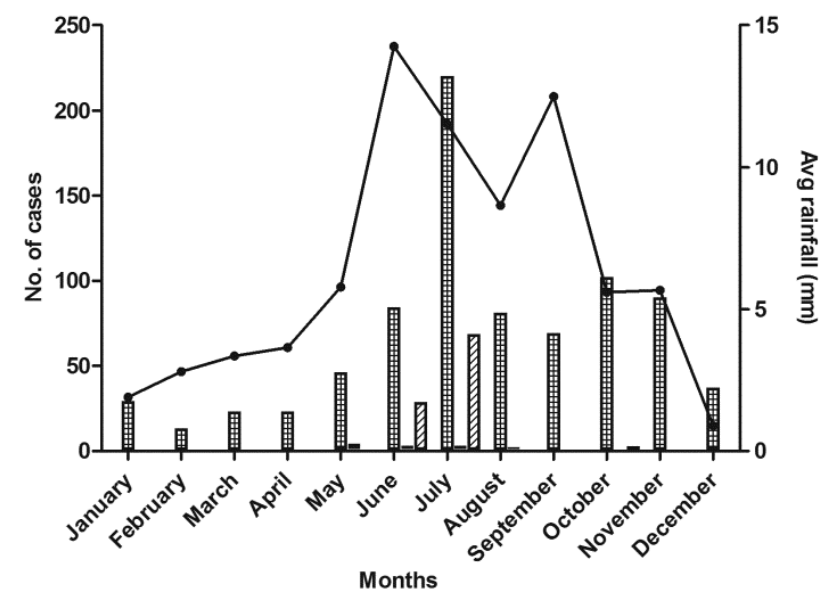

因 No. of Cases

(]) $A(\mathrm{H} 1 \mathrm{~N} 1)$ pdm09

目 $A($ H3N2)

$\rightarrow$ Avg rainfall $(\mathrm{mm})$

of influenza $\mathrm{A}(\mathrm{H} 3 \mathrm{~N} 2)$ in 17 out of $35(48.57 \%)$ patients and $\mathrm{A}(\mathrm{H} 1 \mathrm{~N} 1) \mathrm{pdm} 09$ in one $(2.85 \%)$ patient. Of the total 204 specimens collected, $102(50 \%)$ were laboratory-confirmed influenza A. Out of 102 positive specimens, $96(94.11 \%)$ were influenza $\mathrm{A}(\mathrm{H} 3 \mathrm{~N} 2)$, and $6(5.88 \%)$ were $\mathrm{A}(\mathrm{H} 1 \mathrm{~N} 1) \mathrm{pdm} 09$. Nevertheless, none $(0 \%)$ of the specimens was found to be seasonal influenza $\mathrm{A}(\mathrm{H} 1 \mathrm{~N} 1)$ positive. Influenza type $\mathrm{B}$ could not be detected in 102 type A-negative specimens. Seventeen randomly selected influenza A(H3N2)positive specimens were subjected to virus isolation, and all $(100 \%)$ yielded isolates.

The median age of the influenza $\mathrm{A}(\mathrm{H} 3 \mathrm{~N} 2)$-positive patients was 19.2 years, with a range of 2 months to 91 years. The highest positivity was observed among patients in the age group of $0-5$ years, followed by 15-30 years and 31-44 years. (Table 1). Among the influenza $\mathrm{A}(\mathrm{H} 3 \mathrm{~N} 2)$-positive patients, 60 were female $(62.50 \%)$ and 36 were male $(37.50 \%)$.

The reported symptoms of the patients with laboratory-confirmed influenza $\mathrm{A}(\mathrm{H} 3 \mathrm{~N} 2)$ infections were fever at presentation or within the last three days (temperature $\left.>38^{\circ} \mathrm{C}\right)(89.58 \%)$, cough $(77.08 \%)$, nasal discharge $(52.08 \%)$, sore throat $(47.92 \%)$, vomiting (29.16\%), headache (20.83\%), and chills and rigors $(20.83 \%)$. None of the patients had evidence of severe lower respiratory tract illness or unusual symptoms of influenza such as diarrhea. All patients included in this study responded positively to conservative outpatient treatment and recovered without complications.

During 2011, the predominant activity of influenza $\mathrm{A}(\mathrm{H} 3 \mathrm{~N} 2)$ occurred during the monsoon season, which
Figure 3. Incidence of influenza-like illness cases and laboratory-confirmed influenza $\mathrm{A}(\mathrm{H} 3 \mathrm{~N} 2)$ and $\mathrm{A}(\mathrm{H} 1 \mathrm{~N} 1) \mathrm{pdm} 09$ cases during the outbreak period.

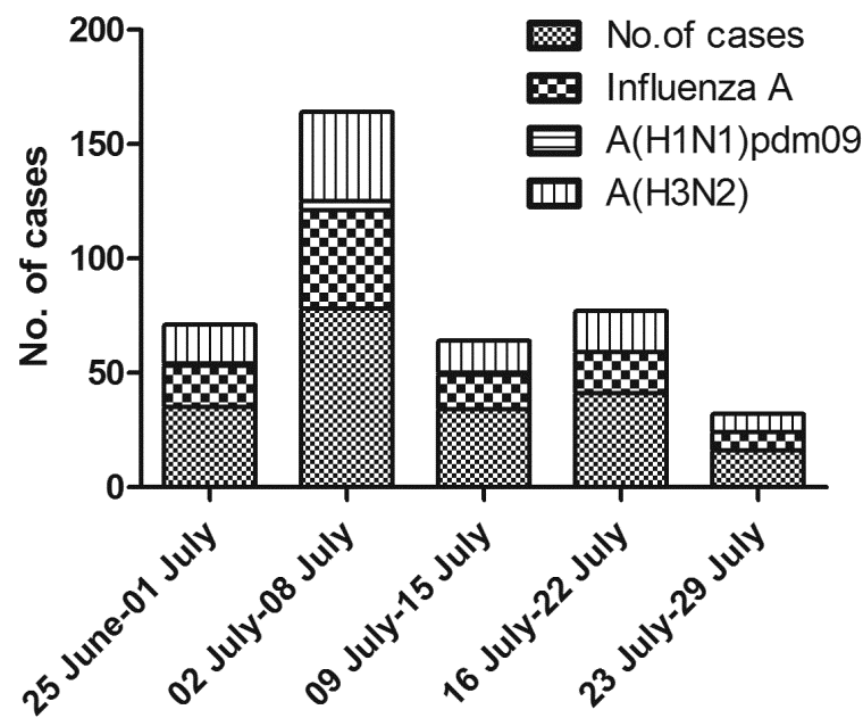

begins by the end of May and lasts until the end of November.Analysis of the results indicated that rainfall had a positive correlation $\left(\mathrm{r}^{2}=0.33, \mathrm{p}=0.050\right)$ with the influenza $\mathrm{A}(\mathrm{H} 3 \mathrm{~N} 2)$ outbreak in Alappuzha district (Figure 2). Figure 3 shows the frequency of ILI cases (those that met the standard ILI definition) during the outbreak period. The initial influenza $\mathrm{A}(\mathrm{H} 3 \mathrm{~N} 2)$ cases occurred in late June, and the highest incidence of laboratory-confirmed influenza A(H3N2) occurred during the first week of July 2011.

HA1 gene of 13 influenza $A(H 3 N 2)$ isolates were sequenced (GenBank accessioning numbers for seven HA1 gene sequences: CY110806, CY110807, CY110808, CY110809, CY110810, CY110811, and CY110812). Phylogenetic analysis revealed the isolates were genetically related to the A/Victoria/361/2011/H3N2 virus. These isolates acquired $\mathrm{K} 158 \mathrm{~N}, \mathrm{~N} 189 \mathrm{~K}$, and T212A mutation as in A/Victoria/361/2011/H3N2. All isolates remained sensitive to oseltamivir. Phylogenetic analysis was rooted in the 2010-2011 northern hemisphere influenza vaccine strain (A/Perth/16/2009/H3N2), and construction was performed using influenza sequences from this outbreak and influenza $\mathrm{A}(\mathrm{H} 3 \mathrm{~N} 2)$ strains circulating in India between 2008 and 2012 (Figure 4).

\section{Discussion}

There have been several episodes of influenza $\mathrm{A}(\mathrm{H} 3 \mathrm{~N} 2)$ outbreaks from various parts of the world, including India $[4,15]$.Nevertheless, no outbreaks of influenza $\mathrm{A}(\mathrm{H} 3 \mathrm{~N} 2)$ had been reported from the southern states of India, such as Kerala. In this study, 
investigation of suspected specimens confirmed that the outbreak was due to influenza virus and that the etiological agent was the influenza $\mathrm{A}(\mathrm{H} 3 \mathrm{~N} 2)$ virus.

It is important to note that the seasonality of influenza in both tropical and temperate regions varies considerably. In temperate regions, there are clear seasonal variations in the occurrence of influenza, with a marked peak in cold winter months. In tropical countries, seasonality is less defined, and viruses circulate throughout the year with one or two peaks during monsoon seasons [16].Several reports have appeared on the seasonality of influenza outbreaks in the tropics during the monsoon season [17].

A surveillance study conducted by the NIV in Pune, India revealed that the ten outbreaks that occurred in various parts of India during the monsoon season of 1978 to 1990 were due to the influenza A(H3N2) virus [15]. During the period 1990-2000 in Pune, influenza $\mathrm{A}(\mathrm{H} 3 \mathrm{~N} 2)$ outbreaks occurred predominantly during the rainy season. The occurrence of the influenza $\mathrm{A}(\mathrm{H} 3 \mathrm{~N} 2)$ outbreak in Alappuzha in the monsoon season of 2011 is consistent with previous experience [18]. The climatic factors such as relative humidity, rainfall, and differences in temperatures may cause the rapid shedding of this virus [19]. Co-circulation of $\mathrm{A}(\mathrm{H} 1 \mathrm{~N} 1) \mathrm{pdm} 09$ and influenza $\mathrm{A}(\mathrm{H} 3 \mathrm{~N} 2)$ virus is not unusual [4]. Co-circulation of both $\mathrm{A}(\mathrm{H} 1 \mathrm{~N} 1)$ pdm09 and influenza $\mathrm{A}(\mathrm{H} 3 \mathrm{~N} 2)$ was reported during the June 2009 monsoon season in eastern India [20]. The dynamic patterns and displacement of one subtype with another may partly be explained by limited immunological cross-reactivity between influenza subtypes [21].

Our study revealed that females were more susceptible to influenza than were males. This could be due to the fact that the close vicinity of homes in Alappuzha and heavy rainfall restricted outdoor activities, forcing females to stay indoors, which perhaps led to high transmission between them. Societal and behavioral factors can influence exposure to viruses differently in males and females [22]. Another important hypothesis is about the role of sex steroids. Influenza A virus dysregulates reproductive function as well as cytokine and chemokine production in females, rendering them significantly more susceptible to disease [23].

The highest rate of infection of all studied groups was reported in infants $(33.3 \%)$. The highest attack rate may be due to the lack of immunity to influenza viruses among infants. A higher attack rate among small children with influenza $\mathrm{A}(\mathrm{H} 3 \mathrm{~N} 2)$ virus was reported from Mongolia [24]. Other studies have also shown that children have high clinical attack rates for influenza $\mathrm{A}(\mathrm{H} 3 \mathrm{~N} 2)$ virus [25-27]. The smaller percentage of positivity in other age groups could be because of immunity from the earlier attacks of the virus. Fever is one of the symptoms in the ILI case definition; however, fever was recorded only in $89.58 \%$ of ILI cases. This could be because patients used antipyretics, which are widespread in India, before they sought medical attention [28].

Diversity in circulating influenza types and subtypes poses a real challenge to vaccine strategies. Comparative analysis of the genetic characteristics of viral isolates with the antigenically selected northern hemisphere influenza vaccine for the year 2010-2011 and 2012-2013 revealed homology with the 20122013 northern hemisphere vaccine strain. Phylogenetic analysis confirmed that influenza $\mathrm{A}(\mathrm{H} 3 \mathrm{~N} 2)$ virus did not mutate significantly during the outbreak investigation period in the affected area.

\section{Conclusions}

An influenza $\mathrm{A}(\mathrm{H} 3 \mathrm{~N} 2)$ outbreak was confirmed in Alappuzha district of Kerala state with a co-circulation of $\mathrm{A}(\mathrm{H} 1 \mathrm{~N} 1) \mathrm{pdm} 09$. No substantial difference in the sequence was observed in the etiological agent, and the virus was found to be sensitive to oseltamivir. Outbreak detection and confirmation of diagnosis are two essential steps in an outbreak investigation. Timely notification to public health authorities and prompt implementation of control measures by health authorities helped to reduce the spread of infection. Studying both the incidence and seasonality of influenza is crucial for the development of effective regional preventive strategies and identification of virus strains for vaccine selection.

\section{Acknowledgements}

The authors acknowledge contributions of the project staff of the National Institute of Virology (NIV) Kerala Unit, Alappuzha. This study was funded by the Indian Council of Medical Research (ICMR), New Delhi. (Grant/Award No.VIR/8/2011-ECD-1).

\section{References}

1. Scott CB, Ratcliffe DR, Cramer EB (1996) Human Monocytes Are Unable to Bind to or Phagocytize $\operatorname{IgA}$ and IgG Immune Complexes Formed with Influenza Virus In Vitro. J Immunol 157: 351-359.

2. Fitzner KA, McGhee SM, Hedley AJ, Shortridge KF (1999) Influenza surveillance in Hong Kong: results of a trial Physician Sentinel Programme. Hong Kong Med J 5: 87-94. 
3. Wilson IA, Cox NJ (1990) Structural basis of immune recognition of influenza virus hemagglutinin. Annu Rev Immunol 8: 737-787.

4. Liu W, Li ZD, Tang F, Wei MT, Tong YG, Zhang L, Xin ZT, Ma MJ, Zhang XA, Liu LJ, Zhan L, He C, Yang H, Boucher CA, Richardus JH, CaoWC (2010) Mixed Infections of Pandemic H1N1 and Seasonal H3N2 Viruses in 1 Outbreak. Clin Infect Dis 50: 1359-1365.

5. Tandale BV, Pawar SD, Gurav YK, Chadha MS, Koratkar SS, Shelke VN, Mishra AC (2010) Seroepidemiology of pandemic influenza A(H1N1) 2009 virus infections in Pune, India. BMC Infect Dis 10: 255.

6. Russell CA, Jones TC, Barr IG, Cox NJ, Garten RJ, Gregory V, Gust ID, Hampson AW, Hay AJ, Hurt AC, Jong JC, Kelso A, Klimov AI, Kageyama, Tomadina N,Lapedes AS, Lin YP, Mosterin A, Obuchi, M, Odagiri, T Osterhaus, AD Rimmelzwaan, GF Shaw, MW Skepner E, Stohr K, Tashiro M, Fouchier RA, Smith DJ (2008) The global circulation of seasonal influenza A (H3N2) viruses. Science320: 340-346.

7. World Health Organization (2011) Influenza update. Available:

www.who.int/influenza/surveillance_monitoring/updates//201 1_04_08_GIP_surveillance/en/ Accessed on 08 April 2011

8. Mukherjee TR, Agrawal AS, Chakrabarti S, Sarkar MC (2012) Full genomic analysis of an influenza A (H1N2) virus identified during 2009 pandemic in Eastern India: evidence of reassortment event between co-circulating $\mathrm{A}(\mathrm{H} 1 \mathrm{~N} 1) \mathrm{pdm} 09$ and A/Brisbane/10/2007-like H3N2 strains. Virol J 9: 1186.

9. World Health Organization (2008) A practical guide to harmonizing virological and epidemiological influenza surveillance $2008 . \quad$ Available: http://www.wpro.who.int/emerging_diseases/documents/Guid etoHarmonizingInfluenzaSurveillancerevised2302/en/index.ht ml. Accessed 12 October 2011.

10. World Health Organization (2009) Manual on Animal Influenza Diagnosis and Surveillance. Available: http://www.who.int/csr/resources/publications/influenza/whoc dscsrncs20025rev.pdf Accessed on 20 July 2009.

11. World Health Organization (2009) CDC protocol of real-time RTPCR for influenza A (H1N1). Available: http://www.who.int/csr/resources/publications/swineflu/CDC RealtimeRTPCRprotocol_SwineH1Ass-2009_20090428.pdf. Accessed 20 July 2009.

12. Ray K, Potdar VA, Cherian SS, Pawar SD, Jadhav SM, Waregaonkar SR, Joshi AA, Mishra AC (2008) Characterization of the complete genome of influenza A (H5N1) virus isolated during the 2006 outbreak in poultry in India. Virus Genes 36: 345-353.

13. Potdar VA, Chadha MS, Jadhav SM, Mullick J, Cherian SS, Mishra AC (2010) Genetic characterization of the influenza A pandemic (H1N1) 2009 virus isolates from India. PLoS ONE 5: e9693.

14. Tamura K, Dudley J, Nei M, Kumar S (2007) MEGA4: Molecular Evolutionary Genetics Analysis (MEGA) Software Version 4.0. Mol Biol Evol 24: 1596-1599.

15. Rao BL, Banerjee K (1993) Influenza surveillance in Pune, India, 1978-90 Bull World Health Organ 71: 177-181.

16. Fuhrmann C (2010) The Effects of Weather and Climate on the Seasonality of Influenza: What We Know and What We Need to Know. Geography Compass 4: 718-730.
17. Shek LP, Lee BW (2003) Epidemiology and seasonality of respiratory tract infections in the tropics. Paediatr Respir Rev 4: $105-111$.

18. Rao BL (2003) Epidemiology and control of influenza. Natl Med J India 16: 143-149.

19. Rao BL, Gupta NP, Rao CV, Gogate SS, Shah U (1979) Investigation on the outbreak of influenza by A/USSR/77 virus strain in Pune, Maharashtra in 1978. Indian J Med Res 70: 681-686.

20. Mukherjee TR, Agrawal AS, Sarkar M, Lal R, Chakrabarti S, Sarkar MC (2010) Prevalence and epidemiology of pandemic H1N1 strains in hospitals of Eastern India. J Public Health Epidemiol 2: 171-174.

21. Broor S, Krishnan A, Roy DS, Dhakad S, Kaushik S, Mir MA, Singh Y, Moen A, Chadha M, Mishra AC, Lal RB (2012) Dynamic Patterns of Circulating Seasonal and Pandemic A (H1N1) pdm09 Influenza Viruses From 20072010 in and around Delhi, India. PLoS ONE 7: e29129.

22. Theiler RN, Rasmussen SA, Treadwell TA, Jamieson DJ (2008) Emerging and zoonotic infections in women. Infect Dis Clin North Am 22: 755-772.

23. Robinson DP, Lorenzo ME, Jian W, Klein SL (2011) Elevated 17 $\beta$-Estradiol Protects Females from Influenza A Virus Pathogenesis by Suppressing Inflammatory Responses. PLoS Pathog 7: e1002149.

24. Souma NN, Burmaa A, Kamigaki T, Od I, Bayasgalan N, Darmaa B, Suzuki A, Nymadawa P, Oshitani H (2012) Influenza Transmission in a Community during a Seasonal Influenza A(H3N2) Outbreak (2010-2011) in Mongolia: A Community-Based Prospective Cohort Study. PLoS ONE 7: e33046.

25. Tsai HP, Kuo PH, Liu CC, Wang JR (2001) Respiratory viral infections among pediatric inpatients and outpatients in Taiwan from 1997 to1999. J Clin Microbiol39: 111-118.

26. Nguyen HLK, Saito R, Ngiem HK, Nishikawa M, Shobugawa Y, Nguyen DC (2007) Epidemiology of influenza in Hanoi, Vietnam, from 2001 to 2003. J Infect 55: 58-63.

27. Ramamoorthy N, Pillai LC, Gunasekharan P, Elango V, Priya M P, Sheriff AK (2005) Influenza activity among the paediatric age group in Chennai. Indian J Med Res 121: 776779.

28. Chadha MS, Broor S, Gunasekaran P, Potdar VA, Krishnan A, Chawla-SM, Biswas D, Abraham AM, Jalgaonkar SV, Kaur H, Klimov A, Lal RB, Moen A, Kant L, Mishra AC (2012) Multisite virological influenza surveillance in India: 2004-2008. Influenza and Other Respiratory Viruses 6: 196203.

\section{Corresponding author}

Dr. Balakrishnan Anukumar

National Institute of Virology - Kerala Unit

E Block, 2nd Floor, Medical College Hospital Complex

Vandanam P.O, Alappuzha

Kerala, 688 005, India

Phone: + 914772280500

Fax: +91 4772280100

Email: anukumar@icmr.org.in; anukumar74@gmail.com

Conflict of interests:No conflict of interests is declared. 